\title{
IMAGE IN COMMUNICATION: POLISH HIGH SCHOOL STUDENTS AND TEACHERS VIS-À-VIS THE DYNAMIC ASPECTS OF THEIR IMAGE ON THE OFFICIAL INTERNET WEBSITE OF THEIR SCHOOL
}

\author{
MARLENA IWONA BIELAK
}

\section{Introduction}

The paper delves into the concept of image and the possibilities of its interpretation. Accordingly, it presents different definitions of the notion in question and points to the names of scholars analysing it with reference to different academic fields. Particular attention in this paper is drawn to the model by Puppel (2016) that describes image from the static and dynamic perspective. In this paper the aforementioned framework will be applied to research into the dynamic aspects of the image of Polish high school teachers and students that is presented on the official Internet website of their school.

\section{Image}

'Image' constitutes a concept that provides a rich source of ideas for analysis. The basic dictionary definition presents it as "a way in which a given person or thing is perceived and presented" (Słownik języka polskiego PWN; translation mine, M.B.), whereas Dobek-Ostrowska defines it as “(...) a set of characteristics which, 
according to the receiver's opinion, a given entity possesses" (Dobek-Ostrowska, 2005: 60; translation mine, M.B.). The definition by Davis views image as "a complex intellectual or sensual interpretation, a way of perceiving someone or something; the product of mind resulting from deduction based on accessible presumptions, both real and imagined, conditioned by impressions, beliefs, ideas and emotions. Perceptions may be - and often are - intuitive, e.g. they are connected with aesthetic features, basic truths, axioms and basic interpretations" (Davis, 2007: 47; translation mine, M.B.).

With reference to the above, due attention should be drawn to the fact that individuals create their own image everywhere and always. However, they may represent different levels of awareness in terms of the aforementioned phenomenon at given points of time (c.f. Ociepka, 2005; Rogaliński, 2012). Accordingly, there appears a lot of discussion in literature on the cautious generation and maintenance of the type of image that is most suitable or beneficial in different socio-cultural contexts. To exemplify, the concept of corporate image and its creation have been presented by Altkorn (2004); Budzyński (2003); Daszkiewicz and Wrona (2014); Huber (1994); Nowacki (2005); Szymoniuk (2006) and Tkaczyk (2009) inter alios, whereas the idea of political image and its formation have been analysed, among others, by Bobrowska and Garska (2012); Cichosz (2003); Cwalina (2000); Cwalina and Falkowski (2006); Zaręba (2011); Thomson (2001); Dobek-Ostrowska (2005) and Sears, Huddy and Jervis (2008). The theoretical framework that will be applied in this paper is the approach to image by Puppel (2016). Its basic assumptions will be described below.

\section{Puppel's approach to image}

According to Puppel (2016: 109-110), image constitutes an inseparable element of all embodiments that are entities of a double aspect nature characterised by possessing both look and its perception. Image, its possession, manufacturing and maintenance are determined by the idea that "(...) everything in embodiment creates the image of the embodiment in question" (Puppel, 2016: 110; translation mine, M.B). Simultaneously, all embodiments strive to form the type of image that is most beneficial to them. On the basis of the above assumptions, Puppel (2016: 110) postulates the existence of the global image system and image universality law.

Puppel (2016: 111-112) distinguishes between two ways of approaching images: the static way and the dynamic one. The static way of comprehending image signifies (1) the awareness of embodiments (viewed as either biological or culturalinstitutional entities) with reference to their identity developed within the spatialcohabitative system (i.e. in the face of other embodiments that interact with each other in the space that constitutes the arena of life) or (2) the structure itself that 
differentiates between images. The dynamic way of viewing image implies the constant process of undertaking interactive-communicative activities by a given embodiment, which results in constant image production (i.e. constant production of impressions in the mind of the receiver) with the aim of either protecting the embodiment or expressing care for image aesthetics. The above is achieved via two types of signalling oneself, i.e. the so called 'honest or dishonest signalling'. Notably, the dynamics of image may also signify its adaptive rhetoric potential realised in different communicative orders with persuasive aims (Puppel, 2016: 111-112).

As highlighted by Puppel (2016: 112), the concept of image can be applied with particular reference to man. Notably, the state and dynamics of human image in the broad socio-cultural context is determined by the idea 'live and let live' which provides a transcommunicator with the possibility of achieving image success in different communicative orders, cultures, ethnicities and communities. The success in question may be identified with reaching 'image attractiveness' which constitutes some foundation for generating man's 'well-being'.

\subsection{Static approach to the image of man}

With reference to the static approach to the image of man, the awareness of transcommunicators is of twofold nature. It is both the awareness of possessing one's own internal image (understood as a specific opinion of oneself or an immanent picture of oneself) and the awareness of the necessity of using the above internal image to make an appropriate impression on other transcommunicators.

One's own image understood as the static structure of self-representation is presented by Puppel (2016: 113) in the form of a diagram that points to the co-operation of four ontological-constructive features described below.

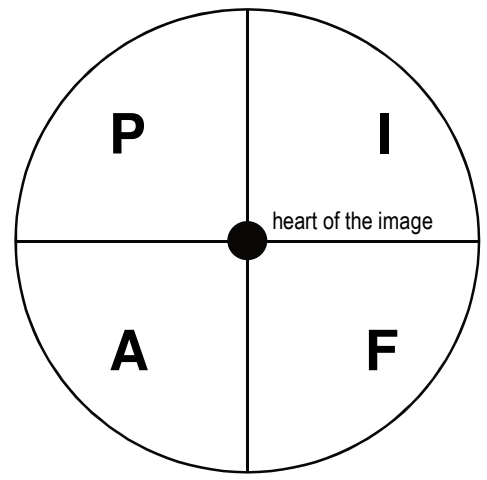

Fig. 1. Image complex of man I-F-A-P (Puppel, 2016: 113) 
1. The awareness of a transcommunictor in terms of the importance of his/her own image (I).

2. Feelings that accompany one's own image $(\mathrm{F})$.

3. One's own assessment of image (A).

4. One's own internal picture of image (P).

The static structure of self-representation underlain by the aforementioned features constitutes 'the image complex of man I-F-A-P' (Figure 1).

\subsection{Image of an object/embodiment (inclusive of man) and its dynamics}

Image dynamics with regards to man pertains to the possibility of performing activities in terms of manufacturing, maintaining and disseminating one's own image complex I-F-A-P in view of both modifying one's image and securing its positive reception by other transcommunicators (Puppel, 2016: 114-116). The above activities, implemented via a wide variety of means accessible to a transcommunicator and applied in relation to particular ontological-constructive features of the image complex of man, constitute a generative mechanism defined by Puppel (2016: 114) as the application of a set number of rules that enable a transcommunicator to perform activities contributing to the production of an image, which comprises 'the dynamics of image strategies' founded on 'image comfort' and its varieties (i.e. 'visual comfort', 'phonic comfort', 'motion comfort' or 'olfactory comfort').

The aforementioned strategies are included in the category 'image architecture' based on the idea of 'structure/system'. The above category can be of holistic character (i.e. focused on completeness) or possess the fragmentary- dispersed nature. Significantly, image activities ought to be characterised by the high degree of 'image effectiveness' (Puppel, 2016: 116), which results in high performance and effectiveness in terms of influencing other transcommunicators and their perception.

\section{Image strategies of man}

Image strategies, which are applied by man within the image complex I-F-A-P, include, inter alia, 'image modality strategies' (Puppel, 2016: 116-117) such as: mono-modality visual strategies (based on the application of one modality, i.e. either the auditory-vocal modality, the visual-tactile one or, to a lesser extent, the olfactory modality), bi-modality visual strategies (engaging two integrated modalities basically the auditory-vocal modality used simultaneously with the visual-tactile modality) and hybrid visual strategies (involving both audio-vocal and visual-tactile modality transmitted via the use of media). 
Additionally, Puppel (2016: 117-118) distinguishes between two types of 'figure strategies': the 'full-figure image strategy' and the 'façade image strategy'. As the names suggest, the full-figure strategy takes into consideration the whole of a given embodiment (i.e. the whole of a person, institution or a block), whereas the façade image strategy is focused on the central part of an embodiment (i.e. the façade of a person, institution or a block).

Image modality strategies and figure strategies may be combined with each other. Significantly, it is the combination of those strategy types that allows the most effective realisation of the image complex. In other words, it is the way in which “(...) a given 'image entity' (e.g. a man, an institution) can provide oneself with the possibility of generating an appropriately integrated and positive (incl. aesthetic) image (...)" (Puppel, 2016: 118).

\section{Policy and economy of image}

Image entities, in order to secure the effectiveness of their activities oriented towards image creation, follow the policy of image based on two assumptions: the strength of image (its strong presence) and the durability of image (its long duration). The strength of image is defined by Puppel (2016: 118-119) as the presence of image based on maximally strengthened parameters (which can be exemplified by size, colour, smell, weight) or intensity, whereas the durability of image relates to the prolonged time dimension of image presence.

Image creation and its exchange, just as all the activities undertaken by embodiments, are subject to the phenomenon of economy and cost-benefit analysis (which, in turn, is connected with achieving an image success). In other words, image activities of embodiments are regulated by the rules of demand and supply. Due to the fact that image economy is closely associated with the basic assumptions of image policy, "[e]conomic activities in terms of generating, maintaining and conserving image are held in accordance with the requirements which can be described by means of almost an Olympic formula: more, longer, stronger, more beautifully" (Puppel, 2016: 120).

\section{Polish schools, their transcommunicators and image}

At present, the functioning of Polish educational institutions is to a large extent determined by such phenomena as demographic decline and heavy competition. Accordingly, schools make heavy efforts to fight for clients (i.e. students). The image of a given educational institution and its creation play a vital role in the above 
process as students and their parents select schools which are perceived most positively in the local environment (Wiśniewska, 2009: 2).

The general image of a given school constitutes the sum total of the images possessed by all the transcommunicators connected with the functioning of the school, i.e. school management and their authorities, teachers, students, parents, administration and school service. The image of the spatial organisation of the school as a building with a variety of rooms contributes to the general image of the school as well.

This paper will concentrate solely on the analysis of selected elements of the image of one type of Polish school (i.e. the Polish high school) which are presented in one particular social-cultural-communicative context. To be more precise, it will delve into the dynamic aspects of the image of Polish high school teachers and students demonstrated on the official Internet website of their school.

\section{Research methodology}

The research rests on the analysis of the content of the official Internet websites of 25 Polish high schools (situated in different regions of Poland) with reference to Puppel's model (2016). As already mentioned, the objective of the analysis is to research into the image dynamics of Polish high school teachers and students presented on the official Internet website of their school.

In other words, the research is to find answers to the questions demonstrated below.

1. Does the process of manufacturing and maintaining the image of the Polish high school student and teacher on the official Internet website of their school result in the image attractiveness of the transcommunicators under analysis?

2. What type of signalling is applied to the process of manufacturing and maintaining the image of the Polish high student and teacher on the official Internet website of their school?

3. Are the requirements of image economy and policy (defined as "more, longer, stronger, more beautifully") satisfied with reference to manufacturing, maintaining and disseminating the image of the Polish high school student and teacher on the official Internet website of their school?

\section{Results of the research}

The results of the research into the dynamic aspects of the image of Polish high school students and teachers presented on the official Internet website, inclusive of the answers to the research questions, will be demonstrated as a set of numbered assertions complemented by conclusions. 
1. The process of generating the image of Polish high school teachers and students on the official Internet website is initiated by presenting the mission of the school, which is slightly different in the case of each educational institution but always conveys the general image of the high school teacher who cares for the student and provides him/her with harmonious and all-embracing development taking into consideration his/her individual talents and intellectual and physical predispositions. The teacher is also responsible for students' upbringing. Therefore, he/she equips them with socially accepted values and respect for others. Analogically, the image of the Polish high school student that is conveyed is the image of a learner who is provided with a congenial educational environment for developing his/her intellectual and socio-cultural potential.

2. The process of manufacturing the image of the Polish high school teacher and student, initiated by the presentation of the school mission, is further expanded by the description of the specified tasks of the teacher and the rights and duties of the student included in the school statute.

3. The image of the Polish high school teacher that is sketched by presenting his/her tasks in the school statute specifies the image of the teacher that is conveyed by the school mission. To be more precise, the image in question depicts the Polish high school teacher as a reliable person who provides students with the required level of knowledge, ensures the appropriateness of didactic processes, and helps to overcome school problems. He/she is just, objective and unbiased. The Polish high school teacher also cares for the life, safety and health of students and supports their psychological and physical development, inclusive of developing their talents and interests. The aim of his/her classes is to shape the student's cognitive curiosity, mental efficiency, criticism and openness. Significantly, the Polish high school teacher is oriented towards broadening his/her own knowledge and developing his/her own didactic skills. He/she takes care of his/her own language aesthetics and that of his/her students.

4. The image of the Polish high school student, which is depicted by describing the student's rights and duties in the statute, broadens the student's image demonstrated in the mission. The image sketched by the statute presents a learner that is placed in an appropriately-organised and equipped environment, where educational processes are properly conducted. In the above space the student is provided with the required level of knowledge, different types of support and is treated with respect. Significantly, in the environment in question the learner's creative potential is realised, his/her special talents individually evolve and interests are developed. The student is also required to perform his duties (connected with being a learner) and avoid examples of inappropriate behavior (which are clearly specified and for which one can be 
punished). As a result of the above, the Polish high school student should become a wise, cultured and open person who possesses knowledge, the skill of critical thinking and is able to differentiate between inappropriate behavior and the positive one.

5. The above image of the Polish high school teacher and student manufactured by the school mission and statute is maintained by different sections of the official school website that present school events and school life. They include presentations of students' educational achievements (e.g. success in competitions), information on learners' voluntary work, their participation and involvement in a variety of activities (e.g. projects, university workshops and lectures) and descriptions of school events and after-school classes that point to teachers' engagement and students' development. Significantly, the presentations of the above activities are complemented by pictures. One can also encounter high-quality films promoting the school which present smiling and happy students and teachers in the environment of their educational institution, films about students possessing passion or films made by students themselves.

6. The image of the Polish high school teacher and student conveyed by the official Internet websites of Polish high schools is highly positive. In other words, the process of manufacturing and maintaining the image under analysis on the official Internet website of the school results in the image attractiveness of the transcommunicators in question. Notably, the above attractiveness rests on image comfort as the official websites of Polish high schools are well-arranged and aesthetic-oriented.

7. Nevertheless, it must be highlighted that the flawless image of Polish high school students and teachers manufactured and maintained on the official Internet website of the school represents a declaration whose goals are not fully realised. The description of cases that confirm the above assumption can be found in Bielak (2015 a-d, $2016 \mathrm{a}-\mathrm{d}$, in press a-d).

8. Due to the above, it is to be realised that the highly positive image of the Polish high school teacher and student manufactured and maintained on the official Internet website of the school serves the function of a promotional tool used - in the face of demographic decline and strong competition to popularise the school in the local environment and attract students.

9. Accordingly, the type of signalling that is applied to the process of manufacturing and maintaining the image of Polish high students and teachers on the official Internet website of the school is honest only to some extent (i.e. the achievements of teachers and students are real but weak aspects, for obvious reasons, are omitted).

10. It is concluded that the process of manufacturing, maintaining and disseminating the image of Polish high school students and teachers on the official 
Internet website of their school satisfies the requirements of image economy and policy (formulated as "more, longer, stronger, more beautifully") as:

a. the information conforming to the image of the Polish high school student and teacher is in abundance. For those who are interested, the official website of the school may be a real time-eater,

b. the information is regularly updated,

c. the image of the Polish high school teacher and student is disseminated via the Internet, which ensures its durability (i.e. the image is present in virtual space for a very long time),

d. the strength (intensity) of the image is considerable, which results from the application of varied communicative tools, i.e. the image of the Polish high school student and teacher is conveyed by such documents as the school mission and statute (which ensures reliability) and it is strengthened (intensified) by films and numerous notes accompanied by pictures. The strength (intensity) of the image also results from the application of various strategies: films make use of the full-figure and façade image strategies combined with hybrid visual strategies, documents and notes involve mono-modality strategies based on the use of the visual-tactile modality, whereas pictures rest on the full-figure and façade image strategies combined with mono-modality strategies involving the use of the visual-tactile modality,

e. all the elements of the official Internet website of Polish high schools that convey the image under analysis are presented in an aesthetic way, i.e. they are properly selected and arranged, whereas the choice of colours is properly matched.

\section{Conclusions}

The paper has portrayed the concept of image with reference to its theoretical background and has applied the framework by Puppel (2016) to research into the image dynamics of the Polish high school teacher and student demonstrated on the official Internet websites of Polish high schools. Notably, the above analysis points to one aspect that is of vital significance with reference to human existence. To specify, due attention should be drawn to the fact that cautious image manufacturing, which constitutes a complex process and results from the work of numerous people, is widely applied to various areas of human life. The above statement seems to be of fundamental importance with reference to individuals who make use of diverse services as the process of image manufacturing to some extent blurs the real state of affairs. 


\section{References}

Altkorn, J. 2004. Wizerunek firmy. Dąbrowa Górnicza: WSB w Dąbrowie Górniczej.

Bielak, M.I. 2015 a. „Rozwijanie umiejętności komunikacyjnych w ramach zajęć z języka polskiego w polskim liceum ogólnokształcącym. Analiza z perspektywy Imperialnego Tetragonu Wcielenia”. In: Puppel, S. (ed.). MOTEK. Motywy ekolingwistyczne: w stronę ekoglottodydaktyki. Poznań: Katedra Ekokomunikacji UAM. 9-30.

Bielak, M.I. 2015 b. "In search of school identity: English language teaching and learning in Polish private high schools as opposed to Polish state high schools". In: Krawiec, M. (ed.). Current issues in foreign language teaching and learning. Regensburg: Sprachlit Verlag. 1-24.

Bielak, M.I. 2015 c. "Ritual communication in the process of English language teaching and learning held in the space of the Polish high school classroom". Annales Universitatis Apulensis. Series Philologica 2.16. 328-340.

Bielak, M.I. 2015 d. "The communicative face of breaks and classroom lessons in view of the multifariousness of communicative forms in the closed space of school: the case of the Polish high school as a contribution to improving the process of internationalization of higher education". Journal of Linguistic and Intercultural Education - JoLIE 8. 35-58.

Bielak, M.I. 2016 a. "A communicative analysis of the arena of the Polish high school classroom as a contribution to the process of enhancing the effectiveness of English language teaching and learning”. In: Bielak, M.I. and J. Taborek (eds.). A dialogic contribution to determinants of glottodidactic space. Piła: Wydawnictwo Państwowej Wyższej Szkoły Zawodowej im. S. Staszica w Pile. 99-113.

Bielak, M.I. 2016 b. "Communicative processes, culture and English language teaching and learning in the space of the Polish high school classroom: the transcommunicator vs. the impact of the language of the Internet". Kwartalnik Neofilologiczny LXIII 1. 6-19.

Bielak, M.I. 2016 c. "English language teaching and learning in the Polish high school classroom: towards the elementary space of home". In: Krawiec, M. (ed.). New insights into language teaching and learning practices. Regensburg: Sprachlit Verlag. 3-19.

Bielak, M.I. 2016 d. "The space navigation category of the lecture hall and the Polish high school classroom in the communicative perspective". In: Bielak, M.I., Popescu, T. and M. Krawczak (eds.). Bridges and not walls in the field of philology. Piła: Wydawnictwo Państwowej Wyższej Szkoły Zawodowej im. S. Staszica. 69-78.

Bielak, M.I. in press a. "English language teaching and learning from the perspective of the Imperial Tetragon of Embodiment".

Bielak, M.I. in press b. "The public space of the Polish high school classroom and the space navigation category of the theatre: a communicative analysis performed for the needs of glottodidactics".

Bielak, M.I. in press c. "Selected elements of knowledge transfer and teachers' communicative behaviours in the perspective of The Trispherical Model of Beauty: the case of the Polish high school classroom".

Bielak, M.I. in press d. „Zarządzanie zasobami komunikacyjnymi w przestrzeni polskiego liceum ogólnokształcącego a atmosfera zachęcająca uczniów do nauki - analiza wybranych aspektów szkolnej komunikacji wewnętrznej w perspektywie ekolingwistycznej”.

Bobrowska, A. and M. Garska. 2012. „Elementy kreacji wizerunku podmiotu politycznego w rzeczywistości wyborczej”. Colloquium Wydziału Nauk Humanistycznych i Społecznych AMW II. 147-164.

Budzyński, W. 2003. Wizerunek firmy. Kreowanie, zarzadzanie, efekty. Warszawa: Poltext.

Cichosz, M. 2003. (Auto)kreacja wizerunku polityka na przykładzie wyborów prezydenckich w III RP. Toruń: Wydawnictwo Adam Marszałek. 
Cwalina, W. 2000. Telewizyjna reklama polityczna. Lublin: Wydawnictwo Towarzystwa Naukowego Katolickiego Uniwersytetu Lubelskiego.

Cwalina, W. and A. Falkowski. 2006. Marketing polityczny perspektywa psychologiczna. Gdańsk: Gdańskie Wydawnictwo Psychologiczne.

Daszkiewicz, M. and S. Wrona. 2014. Kreowanie marki korporacyjnej. Warszawa: Centrum Doradztwa i Informacji Difin.

Davis, A. 2007. Public relations. Warszawa: Polskie Wydawnictwo Ekonomiczne.

Dobek-Ostrowska, B. 2005. Kampania wyborcza: marketingowe aspekty komunikowania politycznego. Wrocław: Wydawnictwo Uniwersytetu Wrocławskiego.

Huber, K. 1994. Image, czyli jak być gwiazda na rynku. Warszawa: Business Press.

Nowacki, R. 2005. Reklama. Warszawa: Centrum Doradztwa i Informacji Difin.

Ociepka, B. 2005. Ksztattowanie wizerunku. Wrocław: Wydawnictwo Uniwersytetu Wrocławskiego.

Puppel, S. 2016. „Kuźnia Hefajstosa czyli krótki zarys teorii wizerunku w komunikacji człowieka”. Scripta Neophilologica Posnaniensia XVI. 109-124.

Rogaliński, P. 2012. Tworzenie wizerunku. http://przegladdziennikarski.pl/tworzenie-wizerunku-a-image/ [last access: 11 Jan. 2017].

Sears, O.D., Huddy, R. and R. Jervis. 2008. Psychologia polityczna. Kraków: Wydawnictwo Uniwersytetu Jagiellońskiego.

Stownik języka polskiego PWN. http://sjp.pwn.pl/ [last access: 10 Dec. 2016].

Szymoniuk, B. 2006. Komunikacja marketingowa. Warszawa: Polskie Wydawnictwo Ekonomiczne.

Tkaczyk, J. 2009. Ksztattowanie wizerunku przedsiębiorstwa usługowego. http://www.epr.pl/ksztaltowa nie-wizerunku-przedsiebiorstwa-uslugowego,marka,1321,1.html. [last access: 17 Dec. 2016].

Thomson, O. 2001. Historia propagandy. Warszawa: Książka i Wiedza.

Wiśniewska, B. 2009. Strategie promocji szkoły w środowisku lokalnym - praktyczne egzemplifikacje. https://www.zsmg.info/pliki/pedagog/STRATEGIE\%20PROMOCJI\%20SZKO\%C5\%81Y\%20W\% 20\%C5\%9ARODOWISKU\%20LOKALNYM\%20-\%20praktyczne\%20egzemplifikacje.pdf [last access: 10 Dec. 2016].

Zaręba, A. 2011. Wizerunek polityka w III RP: kreacje, instrumentarium, kompetencje komunikacyjne. Rzeszów: Wydawnictwo Uniwersytetu Rzeszowskiego. 